\title{
IBN SİNĀ \\ A Philosophical Mysticism OR a Philosophy of Mysticism?
}

\author{
JULES JANSSENS \\ UNIVERSITY OF LEUVEN
}

\begin{abstract}
It is a well-known fact that Ibn Sinnā in the final part of his work al-Ishārāt wa-l-tanbihāt, Pointers and Reminders, extensively uses a mystical vocabulary. Given this fact some scholars have judged that he in this - in all likelihood rather late - work adheres to a kind of mysticism, either religious or, at least, philosophical. Based on a detailed analysis of some of the most significant passages, the present paper offers evidence that such an interpretation does not pay enough attention to the very way in which Ibn Sinā interprets the mystical notions that are undeniably present in the last three sections of the Ishārāt. In fact, Ibn Sinnā's use of them reveals to have nothing, or almost nothing in common with the meaning attributed to them in Sufi-writings, or in (mainly Neoplatonic) 'mystical' philosophy. It is concluded that Ibn Sīnā, in the final part of the Ishārāt, offers what may be labelled a 'philosophical project that rationally interprets mystical terms, expressions, and phenomena', rather than as 'a philosophical mysticism'.
\end{abstract}

\section{Key Words}

Ibn Sīnā, al-Ishārāt wa-l-tanbīhāt, religious mysticism, philosophical mysticism, philosophical interpretation of mysticism.

\section{Ç}

Ibn Sīnā (born ca. 980 - d. 1053), in the West known as Avicenna, is one of the leading scholars in the history of philosophy. As is the case with all great thinkers, his thought has given rise to a wide variety of interpretations. His relationship with mysticism is no exception to that. Recently, Gutas and Morewedge have presented two diametrically opposed views, the former rejecting the presence of any kind of pure mysticism in Ibn Sīnā, the latter clearly 
defending it. ${ }^{1}$ In what follows, I will try to grasp in a precise way how Ibn Sīnā uses mystical terms and to determine whether or not he adheres to any kind of mysticism, i.e., either a religious (Islamic) one or a philosophical (Neoplatonic) one. In this respect, I will mainly concentrate on the three last sections of his alIshārāt wa-l-tanbihāt, Pointers and Reminders. This work has long time been considered as one of the very latest works of Ibn Sinna - a fact that facilitated the view that Ibn Sinna had evolved from an outspoken rationalism to a 'mystical' view. But this very late dating has been seriously challenged and scholars seem now to incline to date this work between 1027 and 1030, hence at least a few years earlier than traditionally believed. ${ }^{2}$ Whatever be the case, there is clearly

1 See Dimitri Gutas, art. 'Avicenna-Mysticism', in Encyclopaedia Iranica, I, 79-83, and ID., 'Intellect without Limits: The Absence of Mysticism in Avicenna', in Maria Cāndida Pacheco and José F. Meirinhos (eds), Intellect et Imagination in Medieval Philosophy. Turnhout: Brepols, 2006, vol. I: pp. 351-72, respectively Parviz Morewedge, The Mystical Philosophy of Avicenna. Binghamton, New York: Global Publications, Binghantom University, 2001, passim (but especially pp. 12-16, where he severely criticizes Gutas' view). For other contemporary views, see my An Annotated Bibliography on Ibn Siña (1970-1989). Leuven: Leuven University Press, 1991, pp. 203-11; First Supplement (1990-1994). Louvain-la-Neuve: FIDEM, 1999, pp. 99-109. To the ones mentioned there, one may now add: Abdelali Elamrani-Jamal, 'Vision contemplative dans les Ishārāt et 'Philosophie orientale' d'Ibn Sīnā', in Journées d'études Avicenne. Marrakech: G.E.I.S., 1999, pp. 145-52 ; Maha Elkaysi-Friemuth, 'Relationship with God through knowledge and love, 'ish $q$, in the Philosophy of Ibn Sīnā ; Comparison and evaluation', in her God and Humans in Islamic Thought, 'Abd al-Jabbār, Ibn Sinna and alGhazäli. London-New York: Routledge, 2006, pp. 74-118; Thomas E. Gaskill, 'The Complementarity of Reason and Mysticism in Avicenna (Ibn Sinā)', in John J. Cleary (ed), The Perennial Tradition of Neoplatonism. Leuven : Leuven University Press, 1997, pp. 443-57; Pierre Lory, 'Avicenne et le soufisme : à propos de la Risāla nayrūziyya', Études de philosophie arabe, special issue of Bulletin des études orientales, 48 (1996): 137-44; Rafael Ramón Guerrero, 'Avicena: sobre el amor. Avicenna on Love', Anales del seminario de Historia de la Filosofía, 25 (2008): 243-59 and Carlos A. Segovia, 'Del entendimiento al Ángel : en torno al lugar de la gnosis aviceniana', in Intellect et Imagination...(see supra), vol. I, pp. 563-69.

2 Jean R. (Y.) Michot, 'La réponse d'Avicenne à Bahmanyār et al-Kirmānī. Présentation, traduction critique et lexique arabe-français de Mubāhatha III', Le Muséon, 110 (1997): 158-63 proposed a rather early date (before 1020), but afterwards revised his opinion, i.e., proposing as date of composition approximately 1027. See his Avicenne. Réfutation de l'astrologie. Beyrouth, Albouraq, 2006, pp. 32*-33* (esp. p. 32*, note 2). This later date is also suggested by David Reisman, The Making of the Avicennan Tradition. The Transmission, Contents, and Structure of Ibn Sin̄ä's al-Mubāhathāt (The Discussions). LeidenBoston-Köln: Brill, 2002, p. 207. The actual redaction of the work most probably dates of that period, but that it seems not a priori excluded that some of the pointers or reminders had already been formulated at an earlier date. 
Ibn Sīnā: A Philosophical Mysticism or a Philosophy of Mysticism?

no room to doubt Ibn Sinnā's rather encompassing use of a mystical - or, at least, mystically inspired - terminology in these sections. However, one may question whether his use corresponds exactly to that of the Islamic sufis, or, if one judges it more philosophically oriented, whether it corresponds with the 'mysticism' of the Neoplatonic philosophers. It has to be stressed, moreover, that the very nature of the Ishārāt - i.e., its being not a systematic exposition, but a collection of small fragments that 'hint' at the truth, but without fully expressing it constitutes a particular difficulty in identifying Ibn Sīnā's precise ideas. Therefore, it is not possible to simply limit oneself to the very letter of the text. But this does not mean that no attention whatsoever has to be paid to that letter. Inside the eighth section of the Ishārāt, the main topic of which is 'happiness', Ibn Sīnā, in a 'Reminder', affirms:

'The attestation of a certain pleasure may be positively sure, but if the intention called dhawq ('taste') does not occur, it is possible that we do not experience a desire (shawq) for it. Similarly, the certainty of a certain harm may be positively sure, but if the intention called muqāsāh ('suffering') does not occur, it is possible that a full awareness regarding it does not happen. An example of the former is the state of the impotent in his inborn disposition (when he is) confronted with the pleasure of sexual intercourse; an example of the latter, is the state of the one who has not suffered the discomfort of illnessess (when he is) confronted with fever. ${ }^{3}$

Of greatest interest is the use of the terminus technicus dhawq. This term designates the external sense of taste. However, in sufism it expresses a higher form of taste. In his famous Book of definitions, Kitāb al-tárî̄āt, al-Jurjānī (d. 1413), articulates its mystical sense as follows:

'With respect to the (profound) knowledge (ma'rifa) of God, it is the expression of the light of a (mystical) knowledge ('irfäni) that the True [i.e., God] throws in the hearts of the 'saints' (awliya $\vec{a}$ ) by means of theophany (tajalli). Thanks to it, they distinguish between the true and the wrong, and this without deriving that (knowledge) from books or other (similar) things'. ${ }^{4}$

3 Ibn Sīnā, Kitāb al-Ishārāt wa-l-tanbīhāt, ed. J. Forget. Leiden: Brill, 1892, p. 193 ; ed. Sulaymān Dunyā. Cairo: Dār al-Ma'ārif, 1971, t. IV, pp. 19-20. My English translation here differs in several respects from that given by Shams C. Inati, Ibn Sina and Mysticism. Remarks and Admonitions, part IV. London-New York: Kegan Paul International, 1996 (the same remark applies to most of the translations that are given later in the paper).

4 Al-Jurjānī, Kitāb al-Tárîfāt, ed. Gustavus Flügel. Leipzig, 1845. Reprinted Beirut: Librairie du Liban, 1985, p. 112. 
It is immediately striking that any reference to God, so typical of and so fundamental in al-Jurjānī's definition, is simply lacking in Ibn Sīnā's affirmation. The latter clearly does not deal with any other-worldly goal. On the contrary, its focus is explicitly on what one can experience in this world. Certainly, Ibn Sinā deals with data that exceed the simple data of the external senses and the normal experiences, more particularly the expectations and feelings that they create in the human beings. He insists that a profound experience - either inborn or acquired - is needed in order to be attracted to the pleasurable or, inversely, to avoid the painfully. This is also the case on the physical level as shown by the given examples of the absence of sexual desire in the impotent individual, or a lack of concern for his having fever in a person who has no serious experience with illness. Given Ibn Sīnā's general low evaluation of physical pleasures, one may deduce that it is a fortiori also the case for higher, i.e., spiritual pleasures (and, inversely, spiritual pains). Hence, the dhawq is a kind of positive experience that permits the human being to strive to things that cause pleasure.

In the next reminder, Ibn Sīnā seems to move in a more mystical direction when he compares the intellectual pleasure of experiencing the clarity of the First Truth with the sensitive pleasure of experiencing sweetness of things such as, e. g., sweets. In both cases of pleasure one has to do with a perfection of the apprehender, although the attained perfection is far from being identical. Intellection, in sharp contrast with sensation, is not concerned with well-defined material things, but with things characterized by pure immateriality; consequently, the pleasure experienced in intellection is no longer restricted to a strictly limited item, as with regard to sensitive acts, but has almost no limitation. Even more important from a mystical point of view is perhaps the explicit mentioning of an experience of the divine clarity, jalli - a word of the very same root as the one signifying 'theophany', i.e., tajalli. Hence, it is almost natural to think that Ibn Sinna alludes here to a divine light that illuminates the one who intellects. However, Ibn Sinā clearly avoids the idea of any uniting with the Divine, or, to put it in other words, of any total obliteration of the self ( $\left.f a n \bar{a}^{\prime}\right)$. Indeed, he emphasizes that the perfection of the intellecting substance is such that the clarity of the First Truth is represented in it according to its possibility to receive from the First Truth the beauty that is proper to It. ${ }^{5}$ In other words,

5 Ibn Sīnā, Kitāâ al-Ishārāt wa-l-tanbīhāt, ed. J. Forget, p. 194; ed. Sulaymān Dunyā, p. IV, 22. The same limitation is present in a somewhat similar affirmation in his Commentary on the Theology, Sharh Kitāb Uthūlūjiya al-mansūb ilā Arisțū, in A. Badawi. Arisțū 'inda l-'Arab. Cairo, 1947, repr. Kuwait: Wakālat al-mațbu'āt, 1978, p. 52 : '...the clarity of the First Good's essence, its reception and (profound) knowledge insofar as is possible', rendered in a somewhat different way by Peter Adamson in his 'Non- 
Ibn Sīnā: A Philosophical Mysticism or a Philosophy of Mysticism?

creatures only have a limited capacity to experience the divine Splendor. Certainly, this does not place Ibn Sīnā automatically outside sufism, but it makes clear that he can at best be allied with moderate Islamic sufism. Allāh's transcendence, so well expressed in the Qur'ān, is hardly compatible with the idea of a mystical union that implies the complete identity of the mystic and the Divine. Ibn Sīnā is strongly opposed to such an idea, as this affirmation in his commentary on book Lambda of Aristotle's Metaphysics shows:

'As to us, in spite of our weak representation of the powerful intelligibles and our being immerged in bodily nature, we nevertheless can arrive in a furtive manner to the point that a conjunction with the First Truth becoming present to us'. ${ }^{6}$

In using the notion of 'conjunction' (ittişāl), not of 'union' (ittihād), Ibn Sīnā makes clear that for him any kind of identification with the Divine has to be avoided. He unmistakenly opposes any kind of mysticism, which, in like manner as al-Halläj, claims an identification between the ' $\mathrm{I}$ ' and the 'Truth' - as expressed in the latter's famous saying Anā l-haqq, 'I am the Truth'. However, it is striking that Ibn Sinā, in the present commentary on Lambda, refers to a conjunction with God, whereas he normally reserves this expression to indicate the relationship between the actualized human intellect and the Agent Intellect, i.e., the last of the ten emanated Intelligences of the superlunar world. Indeed, the life in the Hereafter of the Blessed consists according to this more habitual view in a permanent conjunction with this Intellect. According to it, it looks as if there is no possiblity whatsoever for any direct contemplation of the Divine. However, in his Commentary on the (pseudo-)Theology, Ibn Sīnā speaks of a true direct vision (mushāhada), which 'follows perception when one's aspiration turns in contemplation toward the true One'. ${ }^{7}$ As shown by Gutas, this direct vision deals

discursive Thought in Avicenna's Commentary on the Theology of Aristotle', in Jon McGinnis, with the assistance of David C. Reisman (eds), Interpreting Avicenna: Science and Philosophy in Medieval Islam. Leiden-Boston : Brill, 2004, p. 107.

6 Avicenne (Ibn Sīnā), Commentaire sur le livre Lambda de la Métaphysique d'Aristote (chapitres 6-10), Édition critique, traduction et notes par Marc Geoffroy, Jules Janssens et Meryem Sebti (Études musulmanes, 43). Paris: Vrin, 2014, p. 59, lines 151-52; Ibn Sīnā, Sharḥ Kitāb ḥarf al-lām, in A. Badawi, Arisțū 'inda l-'Arab. p. 27.

7 Ibn Sīnā, Sharh Kitāb Uthūlūjiyā, p. 44 (translation by Dimitri Gutas, 'Intellect Without Limits', p. 368). For a more detailed study of the notion of mushāhada in Ibn Sinnā, see now Meryem Sebti, 'La notion de Mušāhada dans la philosophie d'Avicenne', in Danielle Cohen-Levinas, Géraldine Roux et Meryem Sebti (éds.), Lectures philosophiques de la mystique dans les trois monothéismes. Paris: Hermann, 2015, pp. 187-211. It has to be stressed that Sebti expresses a somewhat different view that the one I present here. It 
with the particular states of a universal, implying that they are accompanied by affective or emotive states, but, above all, it implies an intellectual knowledge that includes the middle term of a syllogism. ${ }^{8}$ Consequently, for Ibn Sinnā there exists no non-syllogistic knowledge of God; therefore, there is no trace of any Neoplatonic mysticism in his thought. ${ }^{9}$ But this seems to be contradicted by the following saying in the Ilāhiyyāt, Metaphysics, of the Shifä':

'The perfection proper to the rational soul consists in its becoming an intellectual world ('älam'aqlī) in which there is impressed the form of the whole ... It thus becomes transformed into an intelligible world that parallels the existing world in its entirety, witnessing that which is absolute good, absolute beneficence, [and] true beauty, becoming united (my emphasis) with it, imprinted with its example and form, affiliated with it, and becoming of its substance?' ${ }^{10}$

is certainly worthy of most serious attention. If I do not discuss it here in any detail, it is because I felt unable to make an in-depth study of her arguments due to time restrictions.

8 Dimitri Gutas, 'Intellect Without Limits', pp. 368-71.

9 This fact is stressed by Peter Adamson, 'Non-discursive Thought in Avicenna's Commentary on the Theology of Aristotle', p. 111.

10 Avicenna, The Metaphysics of the Healing: A parallel English-Arabic text, translated, introduced, and annotated by Michael M. Marmura, Provo, Utah: Brigham Young University Press, 2005, IX, 7, p. 350 (his translation, slightly modified) ; the same affirmation is also present in Ibn Sīnā, al-Najāt, ed. M. Dānesh-Pazhūh, Tehran: Dāneshgah-e Tehran, 1985, p. 686 and Ibn Sīnā, Ahwāl al-nafs (a work that is known under different titles), in A.F. al-Ahwānī, Aḥwāl al-nafs. Cairo: Dār Ihyā̄' al-kutub al'arabiyya, 1952, pp. 130-31. It has to be observed that the wording of the chapter on ma'a $\bar{d}$ (resurrection) in the metaphysical sections of the Shif $\bar{a}$ ' and the Najāt are (almost) identical, and largely also in the Ahwāl - where one has to deal with one significant omission of a passage (see M. Sebti, 'La question de l'authenticité de l'Épitre des états de l'âme (Risāla fi aḥwāl al-nafs) d'Avicenne', Studia graeco-arabica, 2 (2012), p. 354 ) and the presence of a few minor variants. The attribution of this latter work has been questioned by Sebti (in the paper referred to just before), but Dimitri Gutas, in the second, revised and enlarged edition of his Avicenna and the Aristotelian Tradition. Leiden-Boston: Brill, 2014, pp. 477-79, offers, while admitting that the problem of attribution is in need of a detailed investigation, a few indications that make the attribution to Ibn Sīnā possible, and even plausible. Since this issue of attribution is in itself of no significance for the proper topic of the present paper, I will not further investigate it. For our actual purpose, it suffices to observe that in the wording of the present passage the very affirmation of 'becoming united' (muttahid ${ }^{a n}$ ) is present in the three works. But one looks in vain for this verb in the chapter on the life in the hereafter (III, 14) in Ibn Sīnā's (early) Kitāb al-mabda' wa-l-ma'ād, even if one there finds the idea the perfect pleasure of the soul consists in its becoming an intellectual world' (see Ibn Sīnā, Kitāb al-mabda' wa-l-ma'ād, ed. 'Abd Allāh Nūrānī. Tehran: The 
Ibn Sīnā: A Philosophical Mysticism or a Philosophy of Mysticism?

At face value, the present passage implies the acceptance of a complete union between the perfect rational soul and the divine Intellect. If this is the correct interpretation, one must admit with Gardet that Ibn Sinā here presents a kind of ontological and pantheistic identity. ${ }^{11}$ But, as Michot has stressed, the present affirmation is hardly compatible with what Ibn Sinna says elsewhere in his works and, moreover, the idea of a total union is somehow corrected insofar as it is stressed that the soul becomes only an example (mithāl). ${ }^{12}$ Rather than to speak of an union, Ibn Sinā probably wanted to indicate a particular state of the soul, namely one where it, as a completely polished mirror, perfectly reflects the manifestation of the divine essence. It may perhaps be added that Ibn Sinnā, in the framework of the discussion of the divine attributes somewhat earlier, insists that intellect's apprehension of the intelligible is stronger than sensitive apprehension of the sensible because the intellect unites with the intellected object, i.e., the permanent, universal thing, and becomes identical with it, although only in a qualified way, namely 'in some manner'. ${ }^{13}$

Still in the eighth section of the Ishārāt, Ibn Sinnā ascribes the attainment of complete happiness in terms of a reaching the 'world of sanctity ('âlam al-quds)' and happiness to 'the Knowers who are above (moral) imperfection (al-'arifün almutanazzihün)'. ${ }^{14}$ Both the notions of 'world of sanctity' and 'knowers' could be easily understood in a mystical sense were it not that Ibn Sinā adds a further qualification, namely that of 'happiness'. In other words, the world of sanctity is also that of happiness. Since for Ibn Sinnā true happiness consists in a complete conjunction of the soul with the Agent Intellect, the world of sanctity is that to which this Intellect belongs, i.e., the superlunar world. As to the 'knowers', it is specified that in addition to their 'knowledge' a moral perfection is needed in order to attain full happiness. One herein detects Ibn Sinā's usual emphasis on

Institute of Islamic Studies, McGill University, Tehran Branch, in collaboration with Tehran University, 1984, pp. 109-14, especially p. 110, lines 13-15). Note that Ibn Sinā, in all likelihood, derived the notion of 'intellectual world' from the Pseudo-Theology, and thus ultimately from Plotinus' Enneads (see e. g., V.9.9.7).

11 See Louis Gardet, La connaissance mystique chez Ibn Sīnā et ses présupposées philosophiques. Le Caire: IFAO, 1952, pp. 20-21.

12 Jean R. (Y.) Michot, La destinée de l'homme selon Avicenne. Louvain: Peeters, 1986, pp. 99100.

13 Avicenna, The Metaphysics of the Healing, VIII, 7, p. 298, lines 1-3 (= Ibn Sīnā, al-Najāt, p. 592, lines 1-4).

14 Ibn Sīnā, Kitāa al-Ishārāt wa-l-tanbīhāt, ed. J. Forget, p. 195; ed. Sulaymān Dunyā, p. IV, 32. 
the absolute necessity for those who want to enjoy full happiness in the hereafter, to perfect themselves both on the theoretical and on the practical level. ${ }^{15}$ So, it comes as no surprise that Nașīr al-Dīn al-Ṭūsī, in his commentary on this passage, remarks:

'I say: (when using) 'ārif, 'knower', he means the one who is perfect in his intellectual power, while (when using) mutanazz, 'above (moral) imperfection', he means the one who is perfect in his practical power'. ${ }^{16}$

It is obvious that Ibn Sinnā is alluding to his common view of resurrection, which, although outspokenly intellectualistic, does not dismiss the practical life as completely insignificant. Note however that this practical life is never articulated by him in terms of mystical practices, but clearly in terms of respect of the prophet's Sharia. ${ }^{17}$ Therefore, everything indicates that Ibn Sinā presents here in a mystical terminology what he elsewhere articulates in purely rational terms. The human soul can come close(r) to God, namely when it perfects its theoretical as well as its practical intellection, but it never can experience directly the Divine Itself in any way whatsoever.

However, in the ninth section, Ibn Sinnā seems to distinguish between different degrees of 'knowers'. He opens the first 'Reminder' this way:

'In their lives in the present world, the knowers have stations (maqāmāt) and degrees through which they are distinguished to the exclusion of the others. It is as if, while (still) being in their bodily clothes, they had already taken off and removed them up to the point (to attain) (ilā) the world of sanctity'. ${ }^{18}$

In Sufism it was rather common practice to mention the existence of different 'stations'. As such, the present affirmation does not exclude a mystical meaning. Unfortunately, things get very complicated when in what follows Ibn Sīnā refers to a story, entitled Salamān and Absāl, where the former is 'an allegory of what is similar to you' and the latter 'an allegory for your degrees in 'knowledge' if you are among those who know'. In absence of Ibn Sinnā's original tale, one must trust

15 See e. g., Shifā', Ilāhiyyāt, IX, 7, p. 352, lines 10-14 (theoretical perfection) and p. 354, lines 5-6 (regarding the practical, moral perfection of the soul as something that, in addition to theoretical perfection, is required for realizing true happiness).

16 Ibn Sīnā, Kitāb al-Ishārāt wa-l-tanbīhāt, ed. Sulaymān Dunyā, p. IV, 32-3 (beneath Ibn Sinā's text).

17 Most significant in this respect are the chapters 3-5 of book 10 of the Ilähiyyāt of the Shifä'.

18 Ibn Sīnā, Kitāa al-Ishārāt wa-l-tanbīhāt, ed. J. Forget, p. 198 ; ed. Sulaymān Dunyā, p. IV, 47. 
Ibn Sīnā: A Philosophical Mysticism or a Philosophy of Mysticism?

al-Ṭusīi, who pretends to relate faithfully the story and then identifies Salamān with the rational soul and Absāl with the theoretical intellect. ${ }^{19}$ If this is the correct interpretation - and there seems no serious reason to doubt it - it has to do with an allegory explaining the hierarchical structure of the faculties of the soul, including the continuous struggle between them in order to overpower each other (contrary to what one may expect, according to Ibn Sinnā's view the lower powers are in the vast majority of human beings victorious over the higher). Once again, this has nothing in common with mysticism.

Somewhat later, this time in a 'Pointer', Ibn Sinnā deals with the first stage in the degrees of 'knowledge':

'The first of the degrees of the knowers' movements is that which they themselves call 'the Will'. This is what overcomes the one who scrutinizes what is demonstratively certain, or whose soul is trusting in the holding of the faith, out of a longing for an attachment with the 'firm handhold' (al-'urwa l-wuthqa) ${ }^{20}$ Hence, the procession of such person is towards (the place of) sanctity in order to obtain the refreshment of the conjunction. As long as one remains on this level, one is a murìd, a 'novice". ${ }^{21}$

Ibn Sīnā qualifies the person who belongs to this first degree in purely Sufi-terms as a murid, a 'novice'. This term is of the same root, i.e., $w r d$, as the word iräda, 'will'. However, what exactly is involved in this will? For Ibn Sīnā, this is either sure knowledge, based on demonstration proper, burhān (i.e., demonstration as understood by Aristotle in the Posterior Analytics), or a genuine faith in the divine Revelation. Once again, one easily detects here the complementarity between theoretical and practical perfection. The former requires absolutely irrefutable knowledge, in other words one that is strictly demonstrative, not dialectical in nature; as to the latter, its basis lies in an unconditional trust in the prescriptions of the Sharia. Moreover, Ibn Sinā identifies the object of this will not with the divine Will, but with the world of sanctity, where one finds the Agent Intellect, the proper object of the human soul's ultimate conjunction. All this sharply contrasts with genuine mysticism, especially of a religious kind as the following affirmation of Ibn al-'Arabī makes evident:

'The 'novice' is the one who in view of Allāh get separated from examination and scrutiny, who withholds from his (own) will. And then he knows that only what

19 A good summary of the tale, and its explanation, as given by Ṭūsī is present in Shams C. Inati, Ibn Sina and Mysticism, pp. 31-33.

20 This is a Qur'anic expression, see s. 2, v. 156 and s. 31, v. 22.

${ }^{21}$ Ibn Sīnā, Kitāb al-Ishārāt wa-l'tanbīhāt, ed. J. Forget, p. 202; ed. Sulaymān Dunyā. p. IV, 76-8. 
God, and nobody else, wills, occurs in existence. Thus, he abolishes his will, and, consequently, he does not will anything else than what the True wills'. ${ }^{22}$

In direct opposition to Ibn Sinnā, Ibn al-'Arabī stresses the need to abandon any kind of scrutiny and the complete absorption of one's own will in that of the Divine being. Any intellectual dimension has totally disappeared and the fullness of self-realization is directly linked with the Divine.

In the next pointer, Ibn Sīnā stresses the importance of riyāḍa, 'exercise':

'Exercise' is directed toward three goals:

a. the removal of what is other than the truth (al-haqq) from the path of predilection;

b. to submit the commanding soul (al-nafs al-ammāra) to the tranquil soul (al-nafs al-mutma'inna) ${ }^{23}$ in order to attract the powers of imagination and estimation to 'ideas' (tawahummāt) related to the holy reality (al-amr al-qudsī), (while) leaving the 'ideas' related to the lower reality;

c. render subtle the innermost center (of the soul) (al-sirr) in view of (its being) alert. ${ }^{24}$

The expression of the first goal is not free from some ambiguity insofar as the Arabic word al-haqq can refer to the truth in its epistemological sense, but also to Allāh. ${ }^{25}$ This ambiguity does not disappear when Ibn Sinnā, inside the same 'Pointer', indicates 'true asceticism' - which he had previously described as consisting in the abstinence of whatever one distracts in one's innermost self from the 'truth' - as the best 'exercise' for this goal. As to the second goal, it clearly expresses the necessity of the submission of the animal soul, with its many passions, to the rational soul. In this respect, the powers of imagination and estimation, which largely abstract the data of the senses from materiality and thus prepare to the grasp of the 'pure ideas' by the intellect, must be directed to what is essentially higher, in other words have to be put at the complete service of the intellect. This is part of the basics of Ibn Sinā's noetics. Certainly,

22 Quoted in Al-Jurjānī, Kitāb al-tárîfāt, p. 221.

23 This double characterization of the soul might have been inspired by the Qur'an, s. 12, 53, respectively s. 89 , v. 27.

24 Ibn Sīnā, Kitāb al-Ishārāt wa-l-tanbihhāt, ed. J. Forget, p. 202 ; ed. Sulaymān Dunyā, p. IV, 78-80.

25 See my 'Ibn Sīnā's ideas of ultimate realities: Neoplatonism and the Qur'ān as problem-solving paradigms in the Avicennian system', Ultimate Reality and Meaning, 10 (1987), p. 268. 
Ibn Sīnā: A Philosophical Mysticism or a Philosophy of Mysticism?

he specifies that acts of worship can contribute to have the right attitude in this respect, but he immediately adds that they have been accompanied by fikr, 'discursive thought'. What looks more mystical is the mention of listening to 'melodies' as a possible 'way' to perfect oneself - a clear reference to the wellknown, and in mystical circles very popular, phenomenon of samä. Also in this case Ibn Sinnā emphasizes that this constitutes a means put at the disposal of the powers of the soul in order to perfect this latter in itself, not to reach a state of complete ecstasy. Finally, when Ibn Sina points out the eloquence of the preacher as a third contributing element to the realization of the second goal, he clearly has in mind that rethorics is needed for the guidance of the masses, since they are unable to understand correctly some of the most profound truths regarding God and the world, especially when they are straightforwardly expressed. As to the third goal, it particularly insists on the fact that one has to open one's innermost being to the reception of the 'truth'. This is realized by subtle (discursive) thought (al-fikr al-latîif), as well as by righteous love which Ibn Sinnā contrasts with the dominion of the appetite faculty. In all this, one cannot but see the expression of Ibn Sinā's theory of the acquisition of knowledge. Therefore, as Goichon has already observed, the mystical attitude has become a natural one, i.e., one of intellection, and there is no longer mysticism. ${ }^{26}$

In the following 'Pointer', Ibn Sinnā stresses that the 'novice', thanks to his 'exercises', can arrive at a limit where the light of the 'truth' discloses to him furtive glances, which are pleasant as a short lightning that glows up and then extinguishes. Then, he continues:

'This is what they call 'moments' (awqāt). Two ecstatic emotional states (wajdān) surround each moment: one that is (leading) to it, and another that (follows) upon

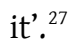

Again, the terminology used is highly mystical, but once again one looks in vain for meanings typical of Sufi writings. Regarding the notion of 'moment', it is obvious that for the Sufis this implies a strong emphasis on the present state of being in touch with the Divine, and thus excluding any attention whatsoever to the past or the future. Moreover, it is stressed that experiencing it is outside human power, and therefore does not result from any efforts on the part of

26 Anne-Marie Goichon, Avicenne. Livre des directives et des remarques. Paris: Vrin, 1951, p. 492, note 1.

${ }^{27}$ Ibn Sīnā, Kitāb al-Ishārāt wa-l-tanbīhāt, ed. J. Forget, p. 202-03; ed. Sulaymān Dunyā, p. IV, 86. 
human beings. ${ }^{28}$ As to the notion of 'ecstatic emotional state', it expresses in Sufism above all a very furtive state of encounter with the Divine, which befalls the heart of the seeker in a mysterious way. ${ }^{29}$ Certainly, taken in itself, one can interpret Ibn Sīnā's affirmation in line with the common Sufi-understanding, but one must then neglect the fact that he has presented this experience as the result of 'exercise(s)'. Moreover, it is striking that he, when dealing with the notion of 'moments', does not say 'we call', but 'they call'. This way of speaking suggests a certain distance to the concerned way of expression and, anyhow, indicates that it is not the terminology preferred by Ibn Sina for talking about these issues. What strikes above all is that the whole passage can easily be interpreted in such a way that it remains completely in line with his usual philosophical account. What Ibn Sīnā seems to refer to can indeed be worded as follows: when one has sufficiently detached oneself from matter, one may open one's soul to an illumination from the Agent Intellect, and thus become fully able to grasp the universal as universal. However, in the beginning, one's conjunctions with the Agent Intellect are of a very short time, especially insofar as one still is much preoccupied with the things of this material world. Only afterwards, through exercise, one may multiply the connections with the Agent Intellect, and receive more easily the related 'illuminations'. Gradually, after a period of time, the reach of illumination will become an habit, so that one will be able to connect with the Agent Intellect whenever one wishes. To attain the truth is then no longer dependent upon a wish, but becomes a permanent disposition. All this finds further support in the 'Pointers' that follow the above quoted one. As to the very final station, Ibn Sīnā expresses it as follows:

'If someone passes over (the stadium of) 'exercise' and arrives at (ilā) (complete) achievement, his innermost center (sirr) becomes a polished mirror, thanks to which he faces the direction of the 'truth'. The highest pleasures overflow him and he is delighted with his soul, due to what is (present) in it of the trace (athar) of the 'truth'. To him belongs a glance at the 'truth' and a glance at himself (or: his soul), while he is still wavering.

Then, he withdraws from his soul and he looks only at the side of (the reality of) sanctity (al-quds), even if he (continues to) look at his soul, but then ( $f a-)$ insofar as

28 See al-Jurjānī, Kitāb al-tárî́fāt, p. 274; see also 'Alī b. Uthmān al-Jullābī al-Hujwīrī, Kashf al-Mahjūb, translated by Reynold A. Nicholson. London, 1911. New Edition, London: Luzac, $1976^{5}$, pp. 367-70.

29 See ibid., p. 270, respectively pp. 413-16. 
Ibn Sīnā: A Philosophical Mysticism or a Philosophy of Mysticism?

his soul is looking (as such at the side of sanctity), not insofar as it is embellished by (this looking). At this point, the arrival becomes true'. ${ }^{30}$

Ibn Sinā uses the analogy of the mirror in order to describe not only the highest destiny of the human soul, but also the fundamental receptivity of the human intellect with respect to the Agent Intellect. It occupies a central place in his noetics since it permits thinking to take place as a specific kind of noetic receptivity, which is different from that of form in matter. ${ }^{31}$ In absence of a proper 'intellectual' memory, the human soul can only enjoy the traces that the intelligibles leave in it when the soul makes itself fully receptive to them. This means that the soul has to direct its attention to the higher world of 'sanctity', given that in itself it has a double glance, i.e., one - upwards - toward the 'truth' and another - downwards - toward itself. One easily detects here an allusion to Ibn Sinā's doctrine of the two faces of the soul, a Neoplatonically inspired doctrine but which he, in all likelihood, derived from Ismailite sources. ${ }^{32}$ Most important with respect to a possible mystical dimension, or absence of it, is his observation that even when the soul regards the higher world, it never becomes completely disconnected from itself. On the contrary, it always has a kind of selfperception, but this disappears at the background as soon as it is profoundly concentrating itself on the higher world of the intelligibles. Note however that it is never completely destroyed. Even in this ultimate stadium, the soul keeps a minimum of its own identity. It may be noted that the term used for 'arrival', i.e., wușull, is of the same root as that by which the 'conjunction' is expressed, i.e., ittișāl. One has here clearly to do with the noetic perfection of the soul, which for Ibn Sina consists in a permanent state of being illuminated thanks to a conjunction of the human soul with the Agent Intellect. One is here far away from any close intimacy with, let alone any extinction in, the divine. Certainly, in detaching oneself gradually from the multiplicity of the material things, one will more and more be enabled to come to a closer grasp of the highest 'truth', i.e., the divine oneness. But this is exclusively by way of intellectual 'contemplation', not by any kind of unification with the divine. In what follows Ibn Sinā

30 Ibn Sīnā, Kitāb al-Ishārāt wa-l-tanbīhāt, ed. J. Forget, p. 204 ; ed. Sulaymān Dunyā, p. IV, 91-3 (2 pointers).

31 These ideas have been well expressed and analyzed into great detail in Meryem Sebti, 'Réceptivité et spéculation dans la noétique d'Avicenne', in Daniël De Smet, Meryem Sebti et Godefroid de Callataÿ (éd), Miroir et savoir. La transmission d'un thème platonicien, des Alexandrins à la philosophie arabo-musulmane. Leuven: Leuven University Press, 2008, pp. 145-71.

32 See Daniël De Smet, 'La doctrine avicennienne des deux faces de l'âme et ses racines ismaéliennes', Studia Islamica, 93 (2003), pp. 77-89. 
enumerates many practical qualities of the 'knower', such as, e. g., being brightfaced, magnanimous, courageous, etc. He notes moreover that between 'knowers' the attitude toward material things may be opposite - depending on whether they do, or do not distract him from the 'truth'. Finally, he stresses that whenever the 'knower' attains the state of conjunction, i.e. theoretical perfection, the 'knower' is no longer subject to religious duties. In fact, these latter only concern the practical life and its perfection. Note that this does not mean that Ibn Sinā simply dismisses religious duties for those who are in search of the truth. As already indicated above, in this life they clearly remain valid for them since they are far from being all the time in conjunction with the Agent Intellect. $^{33}$

In the tenth and last section, Ibn Sinā concentrates on the so-called extraordinary powers of the 'knowers', i.e., abstinence from food for a long time, unusual capacity for action, and knowledge of hidden things. In all three cases he tries to show that they can be explained according to the 'roads' (madhāhib), i.e., the laws, of nature. ${ }^{34}$ Nowhere is there any special divine gift involved. They simply result from the perfection of knowledge present in the 'knower'. Consequently, there is absolutely no place for any supernatural intervention or experience. That some of these acts are perceived as extraordinary is only due to a lack of knowledge. Their naturalness comes to the fore when one sees how greater or lesser long periods of abstinence are related with such phenomena as fear and illness, how we perform extremely powerful acts when excited by anger or joy, or how dreams reveal to us things of the invisible world. Hence, it comes as no surprise when Ibn Sīnā concludes:

'Extraordinary things are dispatched in the natural world out of three principles: -first, the already mentioned psychic dispositions;

-secondly, properties of the elementary bodies, as, for example, the attraction of iron by a magnet, namely by means of a force proper to it;

-thirdly, celestial powers - the adequate correspondence between them and the mixtures of terrestrial bodies that are singled out by positional dispositions, or between them and terrestrial psychic powers that are singled out by astronomical conditions, whether active or passive, result in the origination of extraordinary effects.

33 Same kind of remark in Anne-Marie Goichon, Avicenne. Livre des directives et des remarques, p. 501, note 2 .

${ }^{34}$ Ibn Sīnā, Kitāb al-Ishārāt wa-l-tanbīhāt, ed. J. Forget, p. 207-09; ed. Sulaymān Dunyā, p. IV, 111, 116 and 119. 
Ibn Sīnā: A Philosophical Mysticism or a Philosophy of Mysticism?

Magic is of the first kind; prophetic miracles, miracles of saints and incantations are of the second kind, and, finally, talismans of the third..$^{35}$

In all three cases he simply evokes natural causes, i.e., the basic powers of the human soul, natural powers present in elementary bodies and the natural influence of the stars on terrestrial phenomena, among which the human soul is also included. ${ }^{36}$

From what precedes it is obvious that Ibn Sinnā certainly does not adhere to any kind of religious mysticism. Even when he makes use of classical Islamic mystical terminology, he clearly interprets it in a way that accords with his own philosophical system. Insofar as he seems to naturalize radically each 'mystical phenomenon', one may also seriously doubt that he is an adept of a philosophical mysticism à la Plotinus. ${ }^{37}$ Hence, I think one best qualifies his approach as a 'philosophy of mysticism', or to put it more accurately: a 'philosophical project that rationally interprets mystical terms, expressions, and phenomena', rather than as 'a philosophical mysticism'.

\section{Bibliography}

Adamson, Peter, 'From the necessary existent to God', in Peter Adamson (ed), Interpreting Avicenna. Critical Essays. Cambridge: Cambridge University Press, 2013, pp. 170-89.

Adamson, Peter, 'Non-discursive Thought in Avicenna's Commentary on the Theology of Aristotle', in Jon McGinnis, with the assistance of David C. Reisman

35 Ibn Sīnā, Kitāb al-Ishārāt wa-l-tanbīhāt, ed. J. Forget, p. 221 ; ed. Sulaymān Dunyā, p. IV, 158-59.

36 It has to be noted that Ibn Sinā strongly opposes the science of astrology, see Yahyā Michot, Avicenne. Réfutation de l'astrologie. Beyrouth : Albouraq, 2006, passim.

37 In this context, it is perhaps worthwhile to note that when Ibn Sinā qualifies God as 'above perfection' (fawqa l-tamām) in his metaphysics, this looks as if he simply agrees with the author of the Theology of Aristotle, a work that is largely based on Plotinus' Enneads. However, as Peter Adamson has rightly observed, Ibn Sīnā uses it in a different sense: not to safeguard God's transcendence, but to mark God's causation in addition to His self-sufficiency (see Peter Adamson, 'From the necessary existent to God' in Peter Adamson (ed), Interpreting Avicenna. Critical Essays. Cambridge: Cambridge University Press, 2013, p. 187. 
(eds), Interpreting Avicenna: Science and Philosophy in Medieval Islam. Leiden-Boston: Brill, 2004, pp. 87-111.

De Smet, Daniël, 'La doctrine avicennienne des deux faces de l'âme et ses racines ismaéliennes', Studia Islamica, 93 (2003): 77-89.

Elamrani-Jamal, Abdelali, 'Vision contemplative dans les Ishārāt et 'Philosophie orientale' d'Ibn Sīnā', in Journées d'études Avicenne. Marrakech: G.E.I.S., 1999, pp. $145-52$.

Elkaysi-Friemuth, Maha, God and Humans in Islamic Thought, 'Abd al-Jabbār, Ibn Siñā and al-Ghazāli. London-New York: Routledge, 2006.

Gardet, Louis, La connaissance mystique chez Ibn Sinā et ses présupposées philosophiques. Le Caire: IFAO, 1952.

Gaskill, Thomas E., 'The Complementarity of Reason and Mysticism in Avicenna (Ibn Sīnā)', in John J. Cleary (ed), The Prennial Tradition of Neoplatonism. Leuven: Leuven University Press, 1997, pp. 443-57.

Goichon, Anne-Marie, Avicenne. Livre des directives et des remarques. Paris: Vrin, 1951.

Gutas, Dimitri, Avicenna and the Aristotelian Tradition. Introduction to reading Avicenna's Philosophical Works, second, revised and enlarged edition, including an inventory of Avicenna's authentic works (I.P.T.S., 89), Leiden-Boston: Brill, 2014.

Gutas, Dimitri, art. 'Avicenna-Mysticism', in Encyclopaedia Iranica, I, pp. 79-83.

Gutas, Dimitri, 'Intellect without Limits: The Absence of Mysticism in Avicenna', in María Cândida Pacheco and José F. Meirinhos (eds), Intellect et Imagination in Medieval Philosophy. Turnhout: Brepols, 2006, vol. I, pp. 351-72.

(Al-)Hujwīrī, 'Alī b. Uthmān al-Jullābī, Kashf al-Mahjūb, translated by Reynold A. Nicholson. London, 1911. New Edition: London: Luzac, $1976^{5}$.

[Ibn Sīnā] Avicenna, The Metaphysics of the Healing: A parallel English-Arabic text, translated, introduced, and annotated by Michael M. Marmura. Provo, Utah: Brigham Young University Press, 2005. 
[Ibn Sīnā] Avicenne (Ibn Sīnā), Commentaire sur le livre Lambda de la Métaphysique d'Aristote (chapitres 6-10), Édition critique, traduction et notes par Marc Geoffroy, Jules Janssens er Meryem Sebti (Études musulmanes, 43). Paris : Vrin, 2014.

Ibn Sīnā, Kitāb al-Ishārāt wa-l-tanbihhāt, ed. J. Forget. Leiden : Brill, 1892.

Ibn Sīnā, Kitāb al-Ishārāt wa-l-tanbīhāt, ed. Sulaymān Dunyā. Cairo : Dār al-Ma‘ārif, 1971.

Ibn Sīnā, Kitāb al-mabda' wa-l-ma'ād, ed. 'Abd Allāh Nūrānī. Tehran : The Institute of Islamic Studies, McGill University, Tehran Branch, in Collaboration with Tehran University, 1984.

Ibn Sīnā, Sharh Kitāb ḥarf al-lām, in A. Badawi, Arisțū 'inda l-'Arab. Cairo, 1947, repr. Kuwait, Wakālat al-mațbu'āt, 1978, pp. 12-33.

Ibn Sīnā, Sharh Kitāb Uthūlūjiyāa al-mansūb ilā Arisțū, in A. Badawi. Arisțū 'inda l'Arab. Cairo, 1947, repr. Kuwait, Wakālat al-mațbu'àt, 1978, pp. 35-74.

Inati, Shams C., Ibn Sina and Mysticism. Remarks and Admonitions, part IV, LondonNew York : Kegan Paul International, 1996.

Janssens, Jules, An Annotated Bibliography on Ibn Sinā (1970-1989). Leuven : Leuven University Press, 1991.

Janssens, Jules, An Annotated Bibliography on Ibn Sinnā. First Supplement (1990-1994). Louvain-la-Neuve : FIDEM, 1999.

Janssens, Jules, 'Ibn Sinā's ideas of ultimate realities: Neoplatonism and the Qur'ān as problem-solving paradigms in the Avicennian system', Ultimate Reality and Meaning, 10 (1987): pp. 252-71, reprinted in Jules Janssens, Ibn Sina and his influence on the Arabic and Latin World, (CSS, 843), Aldershot, Hampshire: Ashgate, 2006 , c. II.

Lory, Pierre, 'Avicenne et le soufisme: à propos de la Risāla nayrūziyya', Études de philosophie arabe, special issue of Bulletin des études orientales, 48 (1996): pp. 137-44.

(Al-)Jurjānī, Kitāb al-tárîfāt, ed. Gustavus Flügel. Leipzig, 1845. Reprinted Beirut: Librairie du Liban, 1985.

Michot, Yahyā, Avicenne. Réfutation de l'astrologie. Beyrouth : Albouraq, 2006. 
Michot, Jean R. (Y.), La destinée de l'homme selon Avicenne. Louvain : Peeters, 1986.

Michot, Jean R. (Y.), 'La réponse d'Avicenne à Bahmanyār et al-Kirmānī. Présentation, traduction critique et lexique arabe-français de Mubāḥatha III', Le Muséon, 110 (1997): 143-221.

Morewedge, Parviz, The Mystical Philosophy of Avicenna. Binghamton, New York: Global Publications, Binghantom University, 2001.

Ramón Guerrero, Rafael, 'Avicena: sobre el amor. Avicenna on Love', Anales del seminario de Historia de la Filosofía, 25 (2008): 243-59.

Reisman, David, The Making of the Avicennan Tradition. The Transmmission, Contents, and Structure of Ibn Sinā's al-Mubāḥathāt (The Discussions). Leiden-Boston-Köln : Brill, 2002.

Sebti, Meryem, 'La notion de Mušāhada dans la philosophie d'Avicenne', in Danielle Cohen-Levinas, Géraldine Roux et Meryem Sebti (éds.), Lectures philosophiques de la mystique dans les trois monothéismes. Paris : Hermann, 2015, pp. 187-211.

Sebti, Meryem, 'La question de l'authenticité de l'Épittre des états de l'âme (Risāla fi ahwwāl al-nafs) d'Avicenne', Studia graeco-arabica, 2 (2012): 331-54.

Sebti, Meryem, 'Réceptivité et spéculation dans la noétique d'Avicenne', in Daniël De Smet, Meryem Sebti et Godefroid de Callataÿ (éd.), Miroir et savoir. La transmission d'un thème platonicien, des Alexandrins à la philosophie arabo-musulmane. Leuven: Leuven University Press, 2008, pp. 145-71.

Segovia, Carlos A., 'Del entendimiento al Ángel: en torno al lugar de la gnosis aviceniana', in Maria Cāndida Pacheco and José F. Meirinhos (eds), Intellect et Imagination in Medieval Philosophy. Turnhout : Brepols, 2006, vol. I, pp. 563-69. 